\title{
ASSESSMENT OF RESOURCES IN BAGHMARA COMMUNITY FOREST OF CENTRAL LOWLAND NEPAL
}

\author{
B.K. Sharma ${ }^{1}$ and M.K. Chalise ${ }^{2}$
}

\begin{abstract}
Initial assessment of cost and benefit aspect to the community managed forest for biodiversity conservation was conducted in Baghmara Community Forest at central lowland Nepal. Wildlife was being colonizing and forest was in early succession stage. The area was potential habitat for large wildlife too. Cost-benefit analysis indicated more cost than benefit during the initial stage. Eco-tourism was initiated after a few conservation management efforts in the area that resulted the numbers of tourist influx which will be on profit in near future.
\end{abstract}

Key words: Baghmara, community forest, buffer zone

\section{INTRODUCTION}

Resource degradation has exceeded after the nationalization of private forest (1957) in Nepal mostly due to the unstable government and lack of proper institution for conservation. Later the conservation activities were institutionalized in the form of forest law (early 60's) and protected area law (early 70's) (Chalise 2010). The law enforcement in the protected areas and involvement of local communities in conservation areas moved simultaneously that showed the positive impact on resource conservation (Sharma 1999). The lowland (subtropical) region is famous for economically valuable natural resources like Dipterocarp timber, one horned Rhinoceros, Royal Bengal Tiger and so on. Similarly it consists of the riverine and subtropical forests with flood plain, which are very rich in biodiversity.

In Chitwan, the first step to conserve bio-diversity was initiated with the establishment of rhino sanctuary in 1956 followed by wildlife protection act in 1957. A special unit called rhino patrol was created after a few years to protect rhino (NCRTC 1997). After conservation initiation (1989) in Baghmara, a healthy forest area was created and some endangered flagship species like Asian One Horned Rhinoceros were re-colonized. Then wildlife tourism was started in 1995. Now, this forest is a part of the Buffer Zone of Chitwan National Park (CNP). Conservation efforts have brought significant ecological and socio-economic changes. The changes need to be quantified and assessed before the concept is expanded to the other areas. The institutional engagement in the resource management and the involvement of local stakeholder in process of conservation of the community forest has totally controlled grazing and illegal collection of fuel wood, fodder and hunting. This study will try to analyze the ecological and socio-economic situation during the early phase of its management.

\section{STUDY AREA}

Baghmara Community Forest is located in Bachhauli Village Development Committee of Chitwan District, Nepal (Fig.1). It is situated in Buffer Zone area of Chitwan National Park at eastern sector. It is located in subtropical region of lowland Nepal by covering 215 ha area in between $27^{\circ} 34.78^{\prime}-27^{\circ} 35.53^{\prime}$ northern latitude and 84²8.43'-8429.40' eastern longitude (BBZCF 2003). 


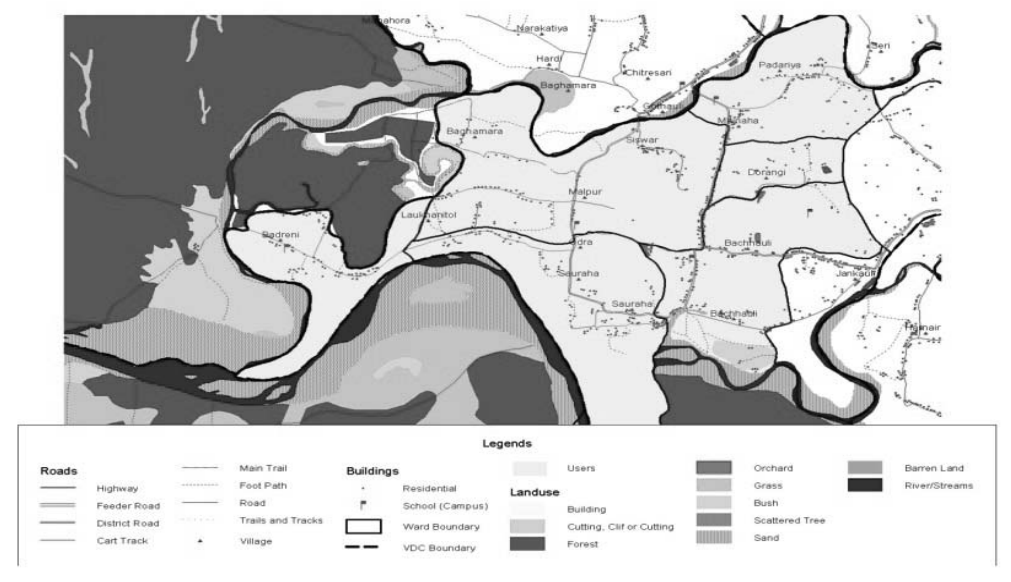

Figure 1. Location of the study area.

The climate of study area is sub-tropical monsoon type with relatively high humidity at an elevation of 200 to 250 meter above sea level. Monsoon rain prevails from late June to September and amount of annual rainfall ranges from $14.04 \mathrm{~mm}$ to $602.2 \mathrm{~mm}$ (Tamrakar 2002). Heavy flooding occurs during the monsoon. The average daily maximum temperature of the area in hot summer days is about $36.8^{\circ} \mathrm{C}$. Spring starts from March and is immediately followed by summer and that ends in June (Pant 2003). The minimum temperature is about $7.8^{\circ} \mathrm{C}$ in cool dry winter season which occurs from October to February (NCRTC 1997).

This community forest is located in the floodplain of Rapti river with majority of riverine forest species. Basically, the dominant species of the forest are Simal (Bombax ceiba), Bhellar (Trewia nudiflora), and Padke (Albizia julibrissin). Other tree species available in the forest are Mallotus phillippensis, Ehertia laevis, Premna integrifolia, Litsea monopetala, Acacia catechu, Dalbergia sissoo and Cordia dichotoma. Similarly, there are some patches of grasslands in the community forest and the major species in the grassland available are Ageratum conyzoides, Peperoxia pellucida, Cyanodon dactylon, Imperata cylindrical, Saccharum spontaneum and Themeda villosa. From the community forest 104 species of plants (including endangered Butea monosperma and Roulfia serpentina) has been recorded (Pant 2003).

The Baghmara Community forest has provided an excellent habitat for the wildlife. It harbors carnivores such as the tiger (Panthera tigris) as frequent visitor and leopard (Panthera pardus). The other main wildlife available in the forest is rhino (Rhinoceros unicornis), spotted deer (Axis axis), sambhar deer (Cervus unicolar), barking deer (Muntiacus muntjack), hog deer (Axis porcinus), wild boar (Sus scrofa), mugger crocodile (Crocodylus palustris), and rhesus monkey (Macaca mulatta)

The first users' group of the Baghmara Community Forest was formed in 1989, which initially included the local residence of Bachhauli Village Development Committee (VDC) ward number 2 and 3 as the member. Later residence ward number 3 and 4 of Bachhauli VDC were included in as its users' with 780 households as the members (49.68\% male and $50.32 \%$ female) (Pant 2003). 


\section{MATERIALS AND METHODS}

For wildlife monitoring was mainly focused on large and flagship species. In early 1995 two permanent transects, covering the different habitats of the study area, were constructed to monitor the wildlife of the area. Monitoring was conducted on monthly basis by using elephants. Equipments for the monitoring mainly included binoculars, GPS and camera. Species, locality and their number was recorded in the field form during the monitoring period.

Basic data to calculate phyto-sociological parameters of the different habitat types were collected by random nested quadrate sampling. Quadrates of $1600 \mathrm{~m}^{2}, 25 \mathrm{~m}^{2}$ and $1 \mathrm{~m}^{2}$ were used to collect data on tree, understory and ground vegetation respectively. From the biggest plot information on trees bigger than $5 \mathrm{~cm}$ DBH were collected. DBH of trees was measured by using Vernier Caliper $(<100 \mathrm{~cm})$ at $1.3 \mathrm{~m}$ height. Height of trees was measured by using a range finder. Those included scientific name, local name, $\mathrm{DBH}$, basal area coverage per species. Information on shrub layer was collected by preparing two $25 \mathrm{~m}^{2}$ nested plots at opposite corners of the $1600 \mathrm{~m}^{2}$ quadrate. From those quadrates information of the species which had woody stems smaller than $5 \mathrm{~cm} \mathrm{DBH}$ and taller than knee height $(40 \mathrm{~cm}$, except grasses) were collected. Collected information included scientific name, local name, crown coverage and number of multiple stems per species. Information on ground vegetation was collected from other four $1 \mathrm{~m}^{2}$ nested plots set at each corner of the $1600 \mathrm{~m}^{2}$ quadrate. Information about ground floras, which included grasses and forbs (lower than $5 \mathrm{~cm} \mathrm{DBH}$ ) and below knee height (except grasses), were collected. Collected information consisted of scientific name, local name and crown coverage per species. Linear measuring tapes, nylon strings and pegs (sticks) were utilized to mark the boundaries of each quadrate. Aluminum frames of $1 \mathrm{~m}^{2}$ were used to demarcate boundaries of quadrates for ground vegetation. A site survey form was prepared for primary data collection. Horizontal coverage of understory and ground vegetation was determined by eye estimation.

Name of each forest was determined by ordering the Importance Values of each tree species. Importance Value was obtained by summation of the relative frequency, relative density, and relative dominance (Krebs 1989). Relative dominance of trees was determined by calculating the basal area. The coverage of ground flora was calculated by converting the recorded cover percentage to midpoint cover classes according to Zobel et al. (1987) (cited in Sharma 1999a). Prominence value of species was calculated by multiplying percent cover of that species with square root of its frequency (Dinerstein 1979). All together the total number of sampling quadrates was 84 . The distribution of sampling quadrates was 12 for trees, 24 for understory and 48 for ground vegetation.

Information regarding cost, benefit, location, history, physiography, climate and natural resource of the study area were obtained from secondary sources. To gather information about the history of the study area knowledgeable persons were interviewed as key informants (Mikkelsen 1995). Plants and large wildlife available in the site were identified either by using local names or from literature. Information about cost and the benefit from the community forest, from start to 1995 , was collected from secondary sources and knowledgeable persons. To calculate Net Present Value of investment cost general 10\% discount rate was utilized. Economic value of the goods which are not sold in the local market, like fodder and grass, was calculated by using shadow price methods (Johnsen 1997). 


\section{RESULTS AND DISCUSSION}

\section{Habitat Types}

The entire study area (215 ha) included three types of habitats namely forest (133 ha), grassland (67 ha) and wetland (15 ha). The forest habitat included both plantation (26 ha) and natural regeneration (107 ha) areas. Grassland incorporated grazing lands as well as scrublands and wetland included oxbow lakes and rivers (BBZCF 2003).

From this study the plantation site included two types of forests, namely Khair-Padke (Acacia catechu and Albizia julibrissin) and pure sissoo (Dalbergia sissoo) forest. In the former forest the Importance value of Khair was found highest (105.9) followed by Padke (59.3) and Sissoo (57.6) respectively. The number of tree per hector of forest land was 1416 and the average height of the tree was $7.2 \mathrm{~m}$. Our current study (2011) showed the number of tree per hector was reduced to 209 individuals. Similarly, the understory layer mainly consists of Urtica dioca $(P V=25)$ and Callicarpa macrophylla (PV = 6.1) respectively. Ground layer of vegetative cover mainly included incorporated Diplazium esculentum ( $P V=9.4)$ and Clerodendrum viscosum $(P V=6.3)$ respectively (Appendix 1 ). In the Sissoo forest most important species was Sissoo $(I V=256)$ and was followed by Bombax ceiba (IV = 15). The most prominent species in understory and ground layer of this forest were Urtica dioca $(P V=29.6)$ and Diplazium esculentum $(P V=28.1$ ) respectively (Appendix 2). In this forest average height of tree was $7.5 \mathrm{~m}$ and tree density was 1759 per hector. From our current study (2011) the number of trees per hector was drastically reduced to 210 individuals. In both of these forests tree diversity was not much changed but was changed in understory vegetation.

The plantation was conducted as two phases, first in 1989 (16 ha) and second in1990 (10 ha), in north western grazing lands of the area (NCRTC 1990). This area was fenced from barbed wire and restricted for grazing. The main planted species were Sissoo, Khair, Bhellor, Simal and Teak (Tectona grandis) (NCRTC 1992). From this study Padke, which was not planted species, came as an important species in Khair forest. This succession appeared at the edge of plantation in mostly from moist microclimate. It indicates that the vegetation was changed according land suitability of the area.

The natural regeneration site included two types of vegetations namely Padke-Bhellor (Albizia julibrissin and Trewia nudiflora) and Simal-Padke (Bombax ceiba- Albizia julibrissin) forest. In the former forest the Importance Value of Padke was found highest (112.7) followed by Bhellor (84.6) and Simal (23.8) respectively (Appendix 3). In this forest, number of trees per hector was 273 and average height of tree was $8.2 \mathrm{~m}$. The most prominent species at understory layer was Caesalpinia decapetala (PV = 87.5) and ground vegetation was absent due to dense canopy cover. In Simal-Padke forest most important species were Simal $(I V=124.2)$ and Padke (IV = 99.3). In this forest average height of tree was $9.3 \mathrm{~m}$ and tree density was 78 per hector. The most prominent species at understory and ground layer of this forest were Litsea sp (PV = 32.5) and Dennstaedtia appendiculata (PV = 6.3) respectively (Appendix 4). From our current study the number of trees per hector of both forests was increased. The diversity of tree species was not much changed but was changed in shrub layer.

The natural regeneration area also protected by community and fencing was completed. Most 
of these areas were inaccessible due to the presence of very dense thorny bush of Caesalpinia decapetala. In these inaccessible areas elephants were used to do plot inventory. It was found quite difficult to work in these areas due to thorny bushes, even from the backup of elephant (NCRTC 1995). Understory layer of Simal-Padke forest consist a good fodder plant and also used to eat by rhino (Jnawali 1995).

\section{Types of Wildlife}

Five species of large wild animals were reported from this forest during 1995. They included wild boar (Sus scrofa), common leopard (Panthera pardus), rhinoceros (Rhinoceros unicornis), marsh mugger (Crocodylus palustris) and sambhar deer (Cervus unicolor) (NCRTC 1995, BCF 1995).

One resident marsh mugger was recorded from Budhi Rapti River situated at the western part of the study area. The available food and less anthropogenic activities due to having deep gorge in the river made it possible to have resident crocodile in the area. The availability of marsh mugger indicated that it will be a favorable habitat for this wildlife. Considering the those fact two more marsh mugger was planning to release in this area.

One resident sambhar deer was recorded from the forest of natural regeneration site (BCF 1995). Anthropogenic activities like grazing, collecting fodder and tree felling were quite common in this area. On average 846 livestock (cattle and buffaloes) were grazed daily and 1300 $\mathrm{kg}$ of fodder were collected daily from this area (BCC 2002). Disturbance of these activities may be one cause of having only one resident sambhar in this area. But, its availability in such disturbance indicated it also can be a potential habitat of sambhar deer.

One injured common leopard and one dead wild boar were reported from the study area (BCF 1995). They may be either resident or migrated from nearby national park. It will be difficult to predict resident leopard without having available food in these area. Even, mush disturbances from the anthropogenic activities will also favor not having resident individual of these two species.

The regular rhino monitoring was started only from November 1995. In total 3-4 rhino were recorded per visit of the rhino monitoring. There was no record of having resident rhino in this area before 1995. The area is one of a good refuge ground for wildlife during the flood and forest fire (NCRTC 1995). In these months agricultural products like wheat and mustards are in early stage of growing and easily available good food for wildlife. During these months other food sources inside national park, like grass and forbs, will be at mature stage and not so palatable to wildlife. So, most of the fringed wildlife used to depredate these agricultural products, especially during night time. Sometimes they used to travel up to $8 \mathrm{~km}$ to depredate crops in the agricultural land and returned to the nearby refuse during early morning (Jnawali 1999). So, that may be the cause of having frequent rhino encounter in the study area during last two months of monitoring. 
Table 1. Status of wildlife species in Baghmara community forest from1989-1995 and 2011.

\begin{tabular}{|l|l|l|l|}
\hline SN & Name & 1989 to 1995 & 2011 \\
\hline 1. & Barking deer & -- & 12 \\
\hline 2. & Hog deer & -- & 2 \\
\hline 3. & Langur monkey & -- & 1 \\
\hline 4. & Leopard & 1 & -- \\
\hline 5. & Marsh Mugger & 1 & 35 \\
\hline 6. & Rhesus monkey & -- & 76 \\
\hline 7. & Rhinoceros & $3-4$ & 3 \\
\hline 8. & Sambhar deer & 2 & 23 \\
\hline 9. & Spotted deer & -- & 182 \\
\hline 10. & Tiger & -- & 1 \\
\hline 11. & Wild boar & 1 & 5 \\
\hline
\end{tabular}

It was found that the number of large wildlife species was 11 . The number of these species was also increased. That indicated the area became a good habitat for the different large wildlife.

\section{Conservation Benefit}

Though initiation for the community management of this area was started from 1987, the actual implementation was started only in 1989 from first plantation (16 ha area). After plantation the area was protected from barbed wire fence associated with rhino proof trenches from livestock and wildlife respectively. In this first plantation 82,517 seedlings of Sissoo, Khair, Teak (Tectona grandis), Bhellor (Trewia nudiflora), and Simal were used. As an early reward of conservation community get NRs. 91,468 during late 1989 by selling thatch grasses. The half portion of this reward was in kind for local community and that was thatch grass. The next plantation was conducted in 10 hector during 1990 (NCRTC 1992). The planted seedlings were the same as the previous year. After these plantations conservation in other areas of this community forest was started only from late 1994. During that period 133 ha area was conserved as natural regeneration site (NCRTC 1997).

Investment for plantation and conservation included the cost for fencing and plantation. That mainly included procurement of poles, wires, seedlings, tools with their transportation and labor cost. The investment was done from then Nepal Conservation Research and Training Center (NCRTC) which is one consortium of then King Mahendra Trust for Nature Conservation (KMTNC) with financial support from WWF US and Biodiversity Conservation Network (NCRTC 1995). Poles for fencing were provided from then Royal Chitwan National Park (NCRTC 1990). Labor for plantation like ground clearing, hole-digging and seedling plantation was done from 
local community (NCRTC 1996).

The other costs for conservation of this area included salary for staffs, cost for habitat improvement, and cost to develop tourism infrastructure Tab 2). The first two costs were covered from their own income. The investment for the tourism infrastructure was also done by same institution from the financial support of same organizations (NCRTC 1997).

Table 2. Total cost (NRs.) of Baghmara community forest from 1989 to 1995/96.

\begin{tabular}{|l|l|}
\hline Headings & Cost (NRs.) \\
\hline Investment & $6,664,414.47$ \\
\hline Salary & $158,567.00$ \\
\hline Wetland rehabilitation & $31,852.50$ \\
\hline Machan (View tower) construction & $250,000.00$ \\
\hline Other cost & $199,998.35$ \\
\hline Total & $7,304,832.32$ \\
\hline
\end{tabular}

Income source of this community included the forest resources like timber, fuel wood, and grass. Beside these forest products the other main income source of the study area was tourism revenue (Tab 3). The innovative idea of the tourism inside the community forest was generated from local tourism entrepreneurs. Some of the entrepreneurs illegally used their private elephant for wildlife tourism inside the community forest (BCF 1995). Location of this forest nearby famous tourism destination of Nepal, called as Sauraha, will be an opportunity to develop tourism in this forest. This potential indirectly forced the community forest users' groups and other stakeholders to think and plan for potential eco-tourism products in this forest. Difficulties to provide salary for forest guards due to lack of financial resources also enforce all the stakeholders to generate revenue from the forest (BCF 1994). From the managed ecotourism there will be not much destruction inside forest, which is one of the positive aspects of the tourism inside the community forest (Cochrane 1999). However, the common tendency of private entrepreneurs is more benefit earning. So, without any mechanism to control the overuse of resources there will be chances of more exploitation of forest resources from private sector (Sharma 2003).

Table 3. Total benefit (NRs.) of Baghmara community forest from 1989 to 1995/96.

\begin{tabular}{|l|l|}
\hline Source & Benefit \\
\hline Forest product selling (timber \& fuel-wood) & $415,636.00$ \\
\hline Tourism revenue (tourist \& elephant entry) & $487,965.00$ \\
\hline Grass collection from local people & $548,800.00$ \\
\hline Thatch grass collection and selling & $91,468.00$ \\
\hline Income from other sources & $37,462.24$ \\
\hline Total & $1,581,331.24$ \\
\hline
\end{tabular}

From the cost and benefit analysis, the cost was much more than the benefit. The analysis 
was done for short period (6 years) when the investment was still ongoing. The tourism influx in the area indicated that the study area will be on benefit side in near future.

From current study it was found that the income of this community forest was in increasing trend. Highest income of this community forest was on fiscal year 2009/2010. In this fiscal year the total income was NRs. 7,772,039.54 (Figure 2). The average income of this community forest was approximately NRs. 38 lakhs per year.

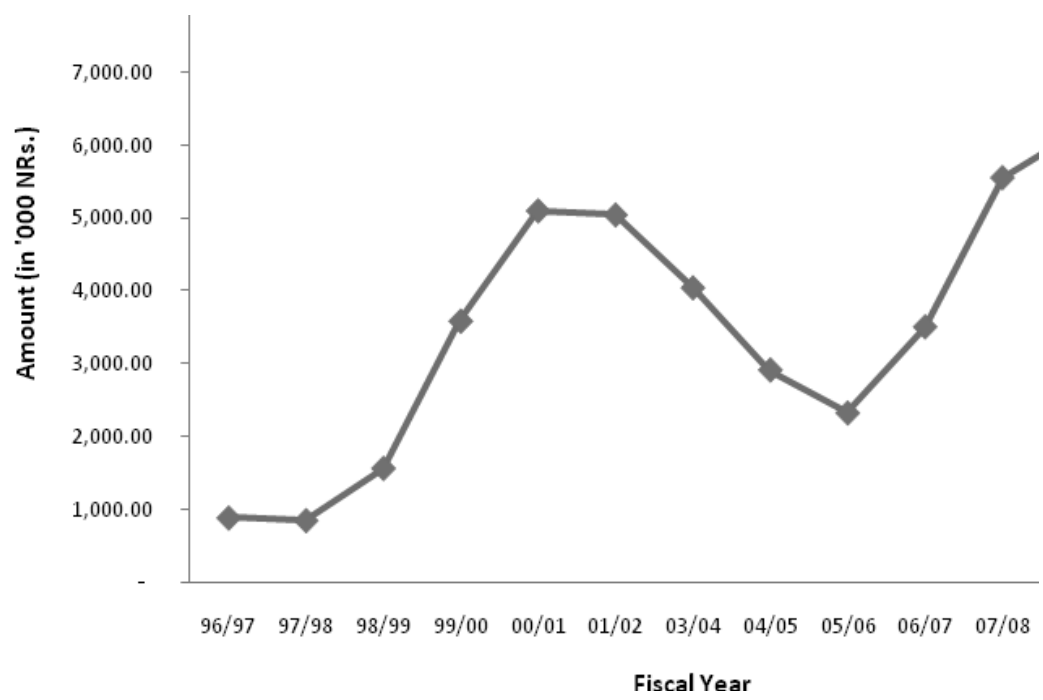

Figure 2. Income status of Baghmara buffer zone community forest from fiscal year $96 / 97$ to $09 / 10$.

Baghmara Community Forest incorporated mosaics of forest, wetlands and grassland habitats suitable for large herbivores. Succession patterns of the forest tree specifically the Albizia julibrissin indicated the area will be converted to a good forest if it conserved from anthropogenic pressure, especially for grazing and timber collection. The area is potential habitats for deer species, monkeys and marsh mugger including endangered rhinoceros. It incorporated potential eco-tourism products which can be a main financial source of this community managed forest.

\section{ACKNOWLEDGEMENTS}

Baghmara Community Forest for providing research permission, Nepal Conservation Research and Training Centre for providing logistic support including assistants and elephant for monitoring. Local people acknowledged for providing required information of this study.

\section{REFERENCES}

Baghmara Buffer Zone Community Forest (BBZCF), 2003. Operational plan of Baghmara buffer zone community forest 2003 to 2007 . BBZCF, Chitwan, $50 \mathrm{p}$.

Biodiversity Conservation Centre (BCC), 2002. Assessment of human pressure inside Barand- 
abhar corridor forest. KMTNC, BCC. 5 p.

Chalise, M.K., 2010. Kehi prakritik srot ra vartaman Nepal (Some Natural Resources and Current Nepal). Praagyik Sansar, Central Campus, TU,12(1):55-65 (in Nepali).

Cochrane, J.,1999. Communities and conservation in Nepals' Terai region: the socio-cultural dynamics of a buffer zone eco-tourism programme in Royal Chitwan National Park. M. Phil. Thesis Submitted to Cambridge University, UK.

Dinerstein, E.,1979. An ecological survey of the Royal Karnali-Bardia Wildlife Reserve, Nepal. Part I: Vegetation modifying factors, and successional relationship. Biol. Conserv., 15:127-150. Jnawali, S.R.,1995. Population ecology of Greater One-horned Rhinoceros (Rhinoceros unicornis) with particular emphasis on habitat preference, food ecology and ranging behavior of a reintroduced population in Royal Bardia National Park in lowland Nepal. Ph. D. Dissertation, Agricultural University of Norway.

Jnawali, S.R.,1999. Assessing rhino-people conflict in Nepal's Royal Chitwan National Park. Unicorn, 1(1):10-17.

Johnsen, F.H.,1997. Introduction to project appraisal. Noragric, Agricultural University of Norway. $15 \mathrm{p}$.

Krebs, C.J.,1989. Ecological methodology. Harper Collins College Publishers, New York.

Mikkelsen, B.,1995. Methods for development work and research. Sage Publications, New Delhi, India.

Nepal Conservation Research and Training Center,1990. Annual report. KMTNC, NCRTC.

Nepal Conservation Research and Training Center, 1992. Annual report. KMTNC, NCRTC.

Nepal Conservation Research and Training Center, 1995. Promoting local guardianship of endangered species and wildlife habitat in Royal Chitwan National Park, Nepal. Progress submitted to Biodiversity Conservation Network.

Nepal Conservation Research and Training Center,1997. Promoting local guardianship of endangered species and wildlife habitat in Royal Chitwan National Park, Nepal. Final technical report submitted to Biodiversity Conservation Network.

Pant, P., 2003. Fuel wood consumption pattern in low land Nepal: A case study in Bagamara Buffer Zone Community Forest, Chitwan, Nepal. M Sc thesis submitted to Pokhara University.

Sharma, U.R.,1999. The concept of "Impact Zone" as applied in Royal Chitwan National Park. Unicorn, 1(1): 5-9.

Sharma, B.K.,1999. Wildlife habitat mapping by using Geographic Information Systems (GIS) in the Karnali floodplain of Royal Bardia National Park at lowland Nepal. M Sc Thesis Submitted to Agricultural University of Norway.

Sharma, B.K., 2003. Eco-tourism in community forest - an example from Baghmara community forest at lowland Nepal. A paper presented in Regional Ecotourism Conference, Gangtok, Sikkim. 
Tamrakar, A., 2002. Resource management in community forest: A case study from Baghmara community forest of Bachhauli VDC, buffer zone of Royal Chitwan National Park. M Sc. Dissertation Submitted to Pokhara University.

Zobel, D.B., M..J. Behan, P.K. Jha and U.K.R. Yadav,1987. A practical manual for ecology. Ratna Book Distributors, Kathmandu, Nepal.

Appendix 1. Importance value (IV) and prominence value (PV) of the plant species in Khair-Padke forest.

\begin{tabular}{|l|l|l|l|l|l|l|l|l|}
\hline Species & Layers & F & C & PV & RF & RD & RDo & I V \\
\hline Acacia catechu & Tree & & & & 14.3 & 46.6 & 45.0 & 105.9 \\
\hline Albizia julibrissin & Tree & & & & 14.3 & 14.8 & 30.2 & 59.3 \\
\hline Dalbergia sissoo & Tree & & & & 14.3 & 27.4 & 15.9 & 57.6 \\
\hline Bombax ceiba & Tree & & & & 14.3 & 7.1 & 4.0 & 25.4 \\
\hline Trewia nudiflora & Tree & & & & 14.3 & 2.9 & 4.6 & 21.8 \\
\hline Litsea monopetala & Tree & & & & 7.1 & 0.4 & 0.1 & 7.6 \\
\hline Toona ciliate & Tree & & & & 7.1 & 0.4 & 0.1 & 7.6 \\
\hline Albizia sp. & Tree & & & & 7.1 & 0.2 & 0.1 & 7.4 \\
\hline Ehertia laevis & Tree & & & & 7.1 & 0.2 & 0.0 & 7.3 \\
\hline Urtica dioica & UL & 1.0 & 25.0 & 25.0 & & & & \\
\hline Callicarpa macrophylla & UL & 0.8 & 7.0 & 6.1 & & & & \\
\hline Colebrookea oppositifolia & UL & 0.3 & 10.0 & 5.0 & & & & \\
\hline Murraya koenigii & UL & 0.3 & 10.0 & 5.0 & & & & \\
\hline Diplazium esculentum & GV & 0.6 & 12.5 & 9.4 & & & & \\
\hline Clerodendrum viscosum & GV & 0.3 & 12.5 & 6.3 & & & & \\
\hline Ageratum conyzoides & GV & 0.5 & 5.0 & 3.5 & & & & \\
\hline Pogostemon benghalensis & GV & 0.4 & 2.5 & 1.7 & & & & \\
\hline
\end{tabular}

Note: $\mathrm{C}=$ Percent cover; F = Frequency; RF = Relative Frequency, RD = Relative Density, RDo Relative Dominance, 
Appendix 2. Importance value (IV) and prominence value (PV) of th plant species in Sissoo forest.

\begin{tabular}{|l|l|l|l|l|l|l|l|l|}
\hline Species & Layers & F & C & PV & RF & RD & RDo & IV \\
\hline Dalbergia sissoo & Tree & & & & 57.1 & 99.2 & 99.7 & 256.0 \\
\hline Bombax ceiba & Tree & & & & 14.3 & 0.6 & 0.1 & 15.0 \\
\hline Anthocephalus chinensis & Tree & & & & 14.3 & 0.1 & 0.1 & 14.5 \\
\hline Albizia julibrissin & Tree & & & & 14.3 & 0.1 & 0.0 & 14.4 \\
\hline Urtica dioica & UL & 0.6 & 37.5 & 29.6 & & & & \\
\hline Colebrookea oppositifolia & UL & 0.4 & 37.5 & 23.0 & & & & \\
\hline Callicarpa macrophylla & UL & 0.4 & 12.5 & 7.7 & & & & \\
\hline Diplazium esculentum & GV & 0.6 & 37.5 & 28.1 & & & & \\
\hline Ageratum conyzoides & GV & 0.5 & 12.5 & 8.8 & & & & \\
\hline Hemarthria compressa & GV & 0.4 & 12.5 & 8.3 & & & & \\
\hline Imperata cylindrica & GV & 0.8 & 2.5 & 2.2 & & & & \\
\hline Eupatorium adenophorum & GV & 0.4 & 2.5 & 1.5 & & & & \\
\hline Piper longum & GV & 0.3 & 2.5 & 1.3 & & & & \\
\hline
\end{tabular}

Note: $\mathrm{C}=$ Percent cover; $\mathrm{F}=$ Frequency; RF = Relative Frequency, $\mathrm{RD}=$ Relative Density, RDo Relative Dominance,

Appendix 3. Importance value (IV) and prominence value (PV) of the plant species in Padke-Vellor forest.

\begin{tabular}{|l|l|l|l|l|l|l|l|l|}
\hline Species & Layers & F & C & PV & RF & RD & RDo & IV \\
\hline Albizia julibrissin & Tree & & & & 21.5 & 46.6 & 44.7 & 112.7 \\
\hline Trewia nudiflora & Tree & & & & 21.5 & 37.2 & 26 & 84.6 \\
\hline Bombax ceiba & Tree & & & & 7.2 & 2 & 14.6 & 23.8 \\
\hline Dysoxylum binectariferum & Tree & & & & 10.7 & 4.1 & 2.5 & 17.2 \\
\hline Caesalpinia decapetala & Tree & & & & 10.7 & 3.3 & 1.2 & 15.1 \\
\hline Ehretia laevis & Tree & & & & 7.2 & 3.1 & 1.8 & 12 \\
\hline Bischofia javanica & Tree & & & & 3.6 & 1.2 & 2.6 & 7.3 \\
\hline Syzygium cumini & Tree & & & & 3.6 & 1.2 & 1.8 & 6.6 \\
\hline Toona ciliate & Tree & & & & 3.6 & 0.4 & 2.6 & 6.5 \\
\hline Mallotus philippensis & Tree & & & & 3.6 & 0.4 & 1.9 & 5.8 \\
\hline Bohori & Tree & & & & 3.6 & 0.4 & 0.7 & 4.6 \\
\hline Litsea monopetala & Tree & & & & 3.6 & 0.4 & 0.1 & 4 \\
\hline
\end{tabular}




\begin{tabular}{|l|l|l|l|l|l|l|l|l|}
\hline Caesalpinia decapetala & UL & 1.0 & 87.5 & 87.5 & & & & \\
\hline Litsea sp. & UL & 1.0 & 2.5 & 2.5 & & & & \\
\hline Colebrookea oppositifolia & UL & 0.3 & 2.5 & 1.3 & & & & \\
\hline Ardisia solanaceae & UL & 0.3 & 2.5 & 1.3 & & & & \\
\hline
\end{tabular}

Note: $\mathrm{C}=$ Percent cover; $\mathrm{F}=$ Frequency; $\mathrm{RF}=$ Relative Frequency, $\mathrm{RD}=$ Relative Density, RDo Relative Dominance

\section{Appendix 4. Importance value (IV) and prominence value (PV) of the} plant species in Simal-Padke forest.

\begin{tabular}{|l|l|l|l|l|l|l|l|l|}
\hline Species & Layers & F & C & PV & RF & RD & RDo & IV \\
\hline Bombax ceiba & Tree & & & & 33.3 & 12.0 & 78.9 & 124.2 \\
\hline Albizia julibrissin & & & & & 16.7 & 76.0 & 6.6 & 99.3 \\
\hline Cleistocalyx operculatus & & & & & 16.7 & 4.0 & 14.1 & 34.8 \\
\hline Syzygium cumini & & & & & 16.7 & 4.0 & 0.2 & 20.9 \\
\hline Litsea monopetala & & & & & 16.7 & 4.0 & 0.1 & 20.8 \\
\hline Litsea sp. & UL & 0.8 & 37.5 & 32.5 & & & & \\
\hline Ardisia solanaceae & UL & 0.5 & 2.5 & 1.8 & & & & \\
\hline Colebrookea oppositifolia & UL & 0.5 & 2.5 & 1.8 & & & & \\
\hline Callicarpa macrophylla & UL & 0.5 & 2.5 & 1.8 & & & & \\
\hline Dennstaedtia appendiculata & GV & 0.3 & 12.5 & 6.3 & & & & \\
\hline Diplazium esculentum & GV & 0.1 & 12.5 & 4.4 & & & & \\
\hline Hemarthria compressa & GV & 0.3 & 2.5 & 1.3 & & & & \\
\hline Achyranthus aspera & GV & 0.1 & 2.5 & 0.9 & & & & \\
\hline Trifolium repens & GV & 0.1 & 2.5 & 0.9 & & & & \\
\hline
\end{tabular}

Note: $\mathrm{C}=$ Percent cover; $\mathrm{F}=$ Frequency; RF = Relative Frequency, RD = Relative Density, RDo Relative Dominance,

\section{AUTHORS' ADDRESS}

Bhuvan Keshar Sharma ${ }^{1}$

Ph D Scholar, Mizoram University, India (email: bhuvan_keshars@hotmail.com)

\section{Mukesh Kumar Chalise ${ }^{2}$}

Central Department of Zoology, Tribhuvan University, Kirtipur, Kathmandu, Nepal 